\title{
Establishing the Crime and Corruption Commission: The reformation of Queensland's premier crime-fighting agency
}

\author{
Michael Briody* \\ PhD, School of Criminology and Criminal Justice, Griffith University, Mt Gravatt, Australia
}

On 1 July 2014, the Crime and Corruption Commission (CCC) commenced operations in Queensland following the passing of the Crime and Misconduct and Other Legislation Amendment Act 2014. After its resounding election win in March 2012, the new Liberal National Party government ordered a review of earlier legislation, the Crime and Misconduct Act 2001. The findings of that review, the Callinan-Aroney report, aroused considerable controversy which was exacerbated in late 2013 when the government discharged members of the Parliamentary Crime and Misconduct Committee, the non-partisan oversight body for the Crime and Misconduct Commission, forerunner to the CCC. These agencies stemmed from the recommendations of the 1987-89 Inquiry into crime and corruption in the State by G.E. Fitzgerald. This article includes a literature review that examines the implementation of the Fitzgerald reforms and then assesses the Callinan-Aroney report. Both that report and the subsequent Bill generated public discussion and comments, including submissions from Fitzgerald, past CMC chairpersons and commissioners, legal associations, academics and others. Many contended that while the government's stated intention was to improve effectiveness in combatting illegality, the legislation would effectively obliterate the reforms that had curbed corruption, criminality and abuse of power in the State since the 1980s.

Keywords: criminal justice reform; policing reform; post-Fitzgerald Queensland; Queensland history; Queensland politics.

\section{Introduction}

On 21 November 2013, in the final hours of the Queensland parliamentary year, the government voted to discharge members of the Parliamentary Crime and Misconduct Committee (PCMC). In Australian political history, the en masse sacking must rank close to Governor-General Sir John Kerr's 1975 dismissal of Prime Minister Gough Whitlam in testing the boundaries of the democratic process. The PCMC was originally constituted as a non-partisan group to monitor the State's premier crime-fighting body, the Crime and Misconduct Commission (CMC).

\footnotetext{
*Email: m.briody@griffith.edu.au
}

Establishing the Crime and Corruption Commission: The Reformation of Queensland's Premier Crime Fighting Agency 
By late March 2014, Queensland Attorney-General Jarod Bleijie had introduced legislation, the Crime and Misconduct and Other Legislation Amendment Bill 2014 to remove the need for bipartisan approval of the PCMC before appointing commissioners. The Liberal National Party (LNP) government's reason for axing the PCMC was alleged bias in the treatment of its appointee, Acting CMC Chairperson Dr Ken Levy. Opposition spokeswoman Jackie Trad stated in Parliament that the government's motives for the dismissal were sinister: "The Newman LNP Government is seeking to destroy the CMC not by abolishing it, but by controlling it" (quoted in Smail, Ryan et al., 2013). G.E. ("Tony") Fitzgerald, whose inquiry led to the establishment of the CMC, stated in a submission to the Legislative Affairs and Community Safety Committee, "The bill before this committee takes the final step needed to remove the commission's independence entirely and bring it completely under government control" (Fitzgerald, 2014; quoted in Vogler \& Viellaris, 2014).

In an earlier move by the government to overhaul the CMC, a report by Justice Ian Callinan and Professor Nicholas Aroney, Review of the Crime and Misconduct Act and Related Matters: Report of the Independent Advisory Panel - the Callinan and Aroney report (2013a) - published its recommendations in April 2013. These not only failed to deal adequately with entrenched systemic problems that have obstructed the Fitzgerald vision for reform in the State, but were subject to criticism by a broad range of stakeholders. A literature review below provides a crosssection of perspectives on the reforms to governance recommended by the Fitzgerald report (1989) and the strategies intended to improve the administration of justice in the State. The findings and main recommendations of the Callinan and Aroney report are then outlined and attention is drawn to issues the report neglected to address, and which might have led to more robust and relevant recommendations. The article then summarises stakeholder comments about the report and subsequent events that are indicative of the approach that the government has taken to the corruption and crime-fighting agency and its parliamentary oversight body. The legislation ostensibly intended to implement the recommendations of the Callinan and Aroney report, the Crime and Misconduct and Other Legislation Amendment Act 2014, is then examined and critiqued.

\section{Literature review}

The relationship between police and politics in Queensland prior to the 1987-89 Fitzgerald Inquiry, and particularly under the long lasting conservative Bjelke-Petersen government (1968-87), has been condemned as being improperly close (Fleming and Lewis, 2002). A sub-culture of corruption grew in the then Queensland Police Force, ${ }^{1}$ that included some from its upper echelons, to which the government turned a blind eye (James, 1974; Condon, 2013) and which the Fitzgerald Inquiry and Report (1989) exposed. A number of academics and writers have commented on the

\footnotetext{
${ }^{1}$ Section 2.1 of the Police Service Administration Act 1990 changed the name of the body to the Queensland Police Service.

Establishing the Crime and Corruption Commission: The Reformation of Queensland's Premier Crime Fighting Agency
} 
reforms Fitzgerald recommended, the extent to which they have been implemented and the degree of success they have achieved. Fleming and Lewis (2002, pp. 83-96) reviewed progress in police reform more than a decade after the Fitzgerald Report. They concluded that the politically charged environment in the wake of the Fitzgerald inquiry greatly assisted the transformation of policing in Queensland. This hypothesis was supported with comparisons to similar reform endeavours in New South Wales and New York following the Wood (1997) and Knapp (1972) Commissions respectively and in Northern Ireland in the wake of the Patten and Hayes Report (1999). In December 1989 Labor was elected to office in Queensland for the first time since 1957, both sides of politics having promised to implement the Fitzgerald report's recommendations "lock, stock and barrel” (Wanna \& Arklay, 2010, p. 609). According to Fleming and Lewis (2002, pp. 93-94) the Queensland experience owed its success largely to a political milieu that was conducive to reform. Having the Criminal Justice Commission (CJC) take charge of the reform process proved a potent strategy, because it circumvented any recalcitrant stance the police force and the Queensland Police Union of Employees might have adopted.

In 2009 the Griffith Law Review commemorated the 20th anniversary of the Fitzgerald Report with a special issue that featured six articles reviewing the status of reform in Queensland. Two articles concentrated on electoral reform and another on whistleblowing law reform and are not reviewed. The first of the other three, by Ransley and Johnstone (2009, pp. 531-543) positioned the Fitzgerald Inquiry in its historical context. They remind us that it led to the jailing of a police commissioner and four National Party ministers of the Crown and numerous convictions of other police. The former premier was tried for perjury as a result of his evidence to the inquiry, and was only saved from conviction by a hung jury, which later was found to have been tampered with by his defence team. Ransley and Johnstone provided a brief outline of the key provisions of the Fitzgerald Report and concluded with a brief introduction to each of the six articles in the collection. These articles critically examined the aftermath of the Fitzgerald Report and the reforms that Fitzgerald recommended. They asked whether Fitzgerald's blueprint for accountable and ethical government was achieved — or indeed was capable of being achieved — and whether it has withstood the test of time.

Prenzler (2009, pp. 576-595) took a critical view of the Fitzgerald Report and its impact in assessing the post-Fitzgerald reforms in the political process, criminal justice and the police. The Fitzgerald Inquiry found that police corruption followed corruption in government - the malapportionment in the electoral system and the absence of many standard curbs on executive power. Despite a series of important reforms stemming from Electoral and Administrative Review Commission's (EARC) recommendations, Prenzler argued that these masked deeper structural problems that the Fitzgerald Report failed to address a bias towards the major parties in a system where only one member represents each electorate; the failure to establish transparency in government decision-making; violations of the principle of appointment on merit; the narrowness of the jurisdiction of the CJC and CMC; and the politicisation of policing. The Fitzgerald Report was critical of the criminal justice system as being piecemeal, fragmented and under-resourced, Establishing the Crime and Corruption Commission: The Reformation of Queensland's Premier Crime Fighting Agency 
and lacking the necessary data to focus and evaluate enforcement strategies. It also characterised the criminal justice system as hypocritical (prohibited activities being widely practised with the knowledge of the authorities) and beset by excessive delays at all stages in the process of investigation and prosecution.

Prasser and Aroney (2009, pp. 596-620) were also pessimistic about the legacy of the Fitzgerald Inquiry. They argued that while the Inquiry was highly unusual in focusing on constitutional, political and administrative processes as the underlying causes of corruption and maladministration in Queensland, it did not address the need for change in Queensland's political and constitutional framework. As noted above, the details of reforms were not outlined in the Fitzgerald Report itself, but were to be developed by the EARC and the CJC. Prasser and Aroney argued that the Fitzgerald Inquiry did not understand that proposed changes could not be implemented and sustained if Queensland's particular form of Westminster democracy, with a unicameral parliament and executive domination, remained intact. They showed that the new agencies were grafted on to the existing system of government, which itself had been labelled by the inquiry as the basic cause of maladministration and corruption. Prasser and Aroney (2009p 599-600) suggested that, despite considerable restructuring of institutions, the way in which Queensland governments have operated since the Inquiry remained largely unchanged. The underlying problems remained - the extra-parliamentary institutions designed to deal with the symptoms had not addressed the underlying causes of "Queensland's easily corrupted system of government”.

In a review of the continuation of the Fitzgerald reform agenda, Lewis (2010, pp. 57-80) examined the restructure of the CJC by the Borbidge National-Liberal Party government, which removed the organised and major crime function from the CJC in 1998 and passed it to a newly formed body, the Queensland Crime Commission (QCC). In 2002 the Beattie Labor government through the Crime and Misconduct Act 2001 merged the two agencies to create the Crime and Misconduct Commission. Lewis's major objection to the Crime and Misconduct Act is that it established a different approach to one of the CMC's key functions, complaints management. In doing so it took the CMC in a different direction from that recommended by Fitzgerald. A devolution strategy was introduced that changed the way in which complaints against police and other units of public administration were dealt with. According to the then chairperson, Brendan Butler, the CMC would focus on more serious and complex misconduct, while less serious matters would be dealt with by the public sector agencies where the alleged misconduct had occurred (CMC, 2002, p. 3). In 2010-11, the CMC retained for investigation only 77 of 5053 complaints received - or around one per cent (CMC, 2011, p. 30). Lewis believed that retaining the trust and confidence of the public was essential to guarantee the continuing existence of any such oversight body. On the issue of confidence, the CMC's own survey of public attitudes in 2010 notes, "Since the 2008 Public Attitudes Survey, there has been a statistically significant decline in the public's confidence that complaints would be properly investigated by public service agencies, the CMC and the Queensland Ombudsman”. Public confidence levels in the CMC declined from 74 per cent

Establishing the Crime and Corruption Commission: The Reformation of Queensland's Premier Crime Fighting Agency 
to 66 per cent between the 2008 survey the 2010 survey (CMC, 2011, p. 31). The CMC did not identify the reasons for the decline.

\section{Political Context and Background to the Callinan-Aroney report}

The political lead-up and context in which the Callinan-Aroney review of the Crime and Misconduct Act 2001 was commissioned and conducted appears to have strongly influenced its findings and recommendations. Six months after the resounding win by the Liberal National Party (LNP) in Queensland at the 24 March 2012 election, the new government ordered that the Crime and Misconduct Act be reviewed (Queensland Government, 2012; ABC News, 2012a). From 51 seats in 2009 in the Legislative Assembly, Labor was reduced to only seven seats, suffering a swing of 15.2 percentage points. The LNP won power for the first time in its history, jumping from 34 to 78 seats to gain the largest majority government ever in Queensland. It was the first outright non-Labor majority since the Queensland Nationals won their last victory in 1986. Katter's Australian Party won two seats and the remaining two were taken by independents. Former Brisbane Lord Mayor Campbell Newman, who led the LNP, took office two days after the election (ABC News: 2012b).

The reasons behind the defeat of the Labor Party under the State's first woman Premier, Anna Bligh included a negative but unsubstantiated campaign against LNP leader Newman promoted through television advertisements. Although Labor's popularity had been steadily declining since the 2009 election (Prasser, 2012, p. 3), public opinion polls indicated its support plummeted in the final week of the election campaign. A Crosby Textor exit poll of voters on Election Day found that the disparaging nature of the Labor campaign was the primary issue influencing voters, with most nominating "political behaviour" as affecting their voting decision (Atkins, 2012). Mr Newman accused Labor of employing smear and innuendo and targeting his family in some of the campaign material involving complaints to the CMC that involved his family's business dealings. The CMC's clear declaration on 16 March 2012 that it had found no evidence of misconduct against Mr Newman (CMC, 2012) completely deflated Labor's campaign.

Yet despite this, none of the three matters the CMC examined during the formal election campaign was a result of a referral by Labor.

Premier Newman and his supporters made their views on the issue of complaints to the CMC clear. Deputy Premier Jeff Seeney, one of the most vocal critics of the CMC, argued that the organisation had allowed itself to be used as a political weapon in the lead-up to the election. At a media conference on 27 September 2012 he declared, "The genuine complainant would not use the fact that they have made a complaint in the political argument. Anyone who is genuinely concerned about something can make a complaint to the CMC and not broadcast it to the world" (quoted in Hurst, 2012). A few days later, at another media conference, Premier Newman ratified that sentiment. On 11 October 2012 the Attorney-General and Minister for Justice Jarrod Bleijie announced the review of the Crime and Misconduct Act 2001 and at media conference on the same day said, "My personal view is matters that are dealt with that are complained of to the CMC Establishing the Crime and Corruption Commission: The Reformation of Queensland's Premier Crime Fighting Agency 
should be kept confidential until such time as the CMC either makes a determination or decides it is in the public interest to go out there with public information about it” (quoted in Hurst, 2012).

Figures, however, confirm the low number of politician-driven complaints that are substantiated or warrant a full investigation. The Brisbane Times reported that over the eight years to 2012, the CMC received a total of 71 complaints made by politicians or councillors against each other in the six months leading up to State and local government elections. Based on a conservative average of around 4,000 annual complaints as shown in CMC Annual Reports for those years, complaints against politicians or councillors constituted only 0.2 per cent of those received. The CMC assessed most of these complaints as requiring no further action, while after a full investigation several were not substantiated. The CMC said one complaint in the lead-up to the 2008 election was substantiated, but the matter was not pursued because an allegation of official misconduct against an elected representative must amount to a criminal offence, not simply a disciplinary matter (Hurst, 2012).

\section{The Inquiry's Advisory Panel and Terms of Reference}

For any review, its terms of reference define its scope and parameters; and those for the inquiry under consideration were succinct. First, it would be undertaken by a two-person expert advisory panel headed by former High Court Justice, the Honourable Ian Callinan along with Professor Nicholas Aroney from the School of Law at the University of Queensland (Queensland Government, 2012, p. 1). The choice of inquisitors was unusual while the timing and the expenditure on the inquiry were questionable. Justice Callinan AC, QC had past associations with commissions of inquiry in Queensland. In 1987 he drafted the initial narrow and restrictive terms of reference that Fitzgerald found necessary to extend on two subsequent occasions to preclude the inquiry being ineffectual. Fitzgerald (2014) later commented, "Callinan had ably represented the National Party Government during the [1987-89 Fitzgerald] Inquiry”. Professor Aroney’s web profile, curriculum vitae and his research and publications include no specific qualifications to suggest he would be an appropriate choice to be on the panel for such an inquiry. ${ }^{2}$ Further, the review was conducted when the Newman government was in the process of dismissing over 14,000 public servants for reasons of austerity (Ironside, 2013a).

Under its second term of reference, the Advisory Panel,

would make such recommendations as it thought fit as to whether the Crime and Misconduct Act 2001 (Qld) (“the Act") and any other associated statutes and regulations should be amended... (Queensland Government, 2012).

It was also tasked "to make recommendations to ensure the prioritisation of focus by the relevant agencies on criminal organisations, major crime, the elimination and prevention of

\footnotetext{
${ }^{2}$ http://www.law.uq.edu.au/academic-staff/staff.php?nm=nicholasaroney\&tab=profilelink.
}

Establishing the Crime and Corruption Commission: The Reformation of Queensland's Premier Crime Fighting Agency 
corruption in public affairs, and timeliness and appropriateness of action by the relevant agencies”. Further, the panel was provided the latitude to deal with such other matters as it believed relevant. The third and last term of reference was a due date in March 2013 for the review's report (Queensland Government, 2012).

\section{The Report's Recommendations}

An executive summary of the report and its recommendations was released on 3 April 2013 (Callinan and Aroney, 2013a) and a redacted version tabled in Parliament on 18 April (Callinan and Aroney, 2013b). Perhaps not surprisingly, among the 17 recommendations of the CallinanAroney report were some that reflected the aspirations expressed at press conferences in September and October 2012 by Campbell Newman, Jeff Seeney and Jarod Bleijie.

The report named five matters that the advisory panel found of concern:

1. that there may be a burgeoning and excessive 'integrity industry' in the State

2. that if there were, was it effective, efficient and economically conducted or even necessary?

3. that what the panel called 'integrity' needed to be taught repeatedly

4. that whether such education as may be necessary was a function best carried out by the CMC

5. whether the CMC truly needed a research function (Callinan \& Aroney, 2013b, p. 204).

The panel's 17 recommendations show how it sought to address and rectify these and other issues and the main ones are summarised as:

- An administrative restructure of the CMC is required because it is becoming increasingly bureaucratic and focuses too much on education instead of investigation.

- There needed to be a reduction of matters being referred to the CMC. This could be achieved by raising the threshold for official misconduct; having complaints accompanied by a statutory declaration to the effect that the complaint is not baseless; replacing the present online complaints system; and amending the Act to allow for the prosecution of baseless complaints.

- A Public Service Commission Inspectorate should be created to replace the Ethical Standards Units currently operated independently by different government departments.

- That ethical standards units within Departments should disappear or at least be greatly reduced.

- It should be an offence for any person, including a CMC officer, to disclose that a complaint has been made to the CMC.

Establishing the Crime and Corruption Commission: The Reformation of Queensland's Premier Crime Fighting Agency 
- Standing Orders of the Parliamentary Committee should be harmonised with such new provisions as are introduced into the Crime and Misconduct Act regarding the confidentiality of complaints.

- The Right to Information Act ought to be amended to restrict Departments and agencies (including the Information Commissioner) from being required to give reasons for refusal to produce documents, the restriction to remain in place for 9 months.

- The Parliamentary Commissioner ought to have the statutory power, and the resources, to investigate all complaints of official misconduct within the CMC.

- That research done by the CMC be limited to that directed by the government.

- Most hearings between the PCMC and the CMC should be held in public. To do otherwise would contradict the transparency for which the CMC stands.

- An implementation group for these recommendations should be established consisting of the Public Service Commissioner, the CMC Chairperson and two others, including a senior lawyer (Callinan \& Aroney, 2013b, pp. 212-220).

The first recommendation for an administrative restructure resulted in a review of the CMC by former Australian Federal Police Commissioner Michael ("Mick") Keelty, whose report was tabled in Parliament on 20 November 2013 and contained 15 recommendations to overhaul the agency (Keelty, 2013).

\section{The government response}

Premier Newman and Attorney-General Bleijie (2013) issued a joint media statement on 3 April 2013 on the release of an executive summary of the report. They indicated that, as per the last recommendation above, an implementation panel of the relevant independent experts with broader non-public service expertise would be appointed to address these policy and operational issues. However, the Government later reneged on this promise, and instead convened a panel comprised entirely of Government appointees: the Director-General, Department of Justice and AttorneyGeneral (Chair); the Director-General, Department of the Premier and Cabinet; the Commission Chief Executive, Public Service Commission; and the Acting Chairperson, CMC (Brown, 2014). On 3 July 2013 the government issued a more comprehensive 34-page response to both the Callinan-Aroney report and another inquiry into the release and destruction of Fitzgerald documents. The response stated,

The government is concerned the CMC is called upon to investigate complaints being inappropriately made for political purposes...The Government is committed to implementing the [report's] recommendations... except numbers 7 and 9 that relate to proceeds of crime confiscation and Standing Orders respectively... by March 2014 (Newman \& Bleijie, 2013).

Establishing the Crime and Corruption Commission: The Reformation of Queensland's Premier Crime Fighting Agency 


\section{What were stakeholders' responses to the Callinan and Aroney report?}

The comments about the Callinan and Aroney report from the Leader of the Opposition (Palaszczuk 2013), the Chair of the PCMC, civil rights groups, a number of academics (Withey \& Dorsett, 2013), the State Ombudsman (Remeikis, A. 2013a) and those concerned with freedom of information (Timmins, 2013) were varied, many arguing that the recommendations in the report were misdirected and inappropriate. A media release by the CMC on the 3 April 2013 conveyed the organisation's reticence to engage with the report: “...the CMC takes the position at this time that it is not appropriate to make any detailed public comment” (CMC, 2013). No CMC media release followed the tabling of the redacted report a fortnight later.

\section{The dismissal of the PCMC}

The events leading to the sacking of the PCMC are informative of the position taken by the LNP government to the structures set in place in the wake of the Fitzgerald report. On 31 October 2013 the Acting CMC Chairperson, Dr Ken Levy (2013) published an opinion piece in The CourierMail newspaper supporting the government's anti-gang legislation, the Vicious Lawless Association Disestablishment Act 2013. The opinion piece led to doubts by the PCMC about Dr Levy's independence (Ryan, 2013). When questioned at a public PCMC hearing on 1 November 2013, Dr Levy denied any contact with the government before the article was published. However, this contradicted a statement from the Premier's chief media adviser, Lee Anderson. The PCMC began to investigate whether Dr Levy had misled it, but the matter was referred to a select ethics committee after the government dismissed the PCMC late on 21 November 2013. Police also began investigating Dr Levy over the same matter after an opposition MP lodged a complaint, because lying to parliament is a criminal offence in Queensland. The select ethics committee suspended the parliamentary inquiry during the police investigation to avoid any suggestion of double jeopardy (news.com.au, 2014).

Griffith University political analyst Paul Williams commented that the dismissal of the PCMC was unprecedented in Australian political history (quoted in Remeikis, 2013b). The government then appointed four LNP MPs to a reconstituted seven-member PCMC (Ironside, 2013b). Tony Fitzgerald's criticism of this move was scathing:

The Government has already appointed an unsuitable Acting Commission Chairman and, in order to protect him from investigation, dismissed members of the parliamentary committee which was inquiring into his inappropriate conduct and appointed other committee members whom it presumably considers to be more compliant (2014).

On 19 March 2014 the government introduced the Crime and Misconduct and Other Legislation Amendment Bill 2014, its stated objectives being to consolidate this arrangement for future PCMC 
appointments and to implement the recommendations of the Callinan-Aroney report (Queensland Government, 2014).

\section{Critique of the Crime and Misconduct and Other Legislation Amendment Bill 2014}

When the Attorney-General and Minister for Justice introduced the Crime and Misconduct and Other Legislation Amendment Bill 2014 into the Queensland Parliament (Queensland Government 2014), it was referred to the Legal Affairs and Community Safety Committee for detailed consideration and public comment. To facilitate this process the policy objectives of the Bill were set out on the Committee's website, ${ }^{3}$ while the Committee was required to report to the Parliament by 30 April 2014.

The Bill, however, contained serious defects which A J Brown, a professor of public policy and law attributed to a flawed policy development process. His submission to the committee pointed out that the main report on which the amendments were based, that of the implementation panel, was not made publicly available. This was significant because, first, the explanatory notes to the Bill claimed that the amendments represented "implementation of the accepted recommendations” of Mr Callinan and Professor Aroney's review panel as well as the relevant PCMC report on key issues (Queensland Parliament, 2013). However, he contended this was not the case, because the proposed amendments either departed from or went significantly beyond the recommendations of the review panel and the PCMC report. Second, neither the explanatory notes nor any known statements of the government to the parliament to date, explained the purpose of these particular amendments. Third, the apparent basis of the amendments lay in the reports of the Implementation Panel which, according to the explanatory notes, had "met on a regular basis and provided reports to the Premier and the Attorney-General and Minister for Justice”, including advice on these amendments (Brown, 2014). In response to his request for the relevant reports that might have explained the amendments, the Department of Premier and Cabinet advised him on 11 April 2014 that documents from the CMC implementation panel were cabinet in confidence and therefore not available.

Professor Brown noted in his submission that the withholding of the implementation panel reports made a fully informed commentary on the Bill difficult, on the grounds that some of its actual purposes remained unknown or unclear. This was not only because some amendments went beyond the review panel's report, but also because the nature of the process followed by the government made it difficult for people in Queensland to understand the relationship between these amendments and the government's stated policy aims with respect to the CMC. He pointed out that:

\footnotetext{
${ }^{3}$ Then online at http://www.parliament.qld.gov.au/work-of-committees/committees/LACSC/inquiries/currentinquiries/CMOLAB2014

Establishing the Crime and Corruption Commission: The Reformation of Queensland's Premier Crime Fighting Agency
} 
- While the Review Panel was ostensibly appointed to review the Crime and Misconduct Act 2001, its report (somewhat inconsistently with its terms of reference) suggested that the Government's true purpose and expectation of the Panel was not a review of whether the legislation was serving its intended purposes, but a wholescale review of the role, powers and operations of the Crime and Misconduct Commission.

- This was confirmed when the Panel reported, because many of the opinions reached and the recommendations it made bore little direct relationship with the terms of reference, and included a wide range of policy and operational issues that the public could not have anticipated would be dealt with by the Review, based on the original terms of reference (Brown, 2014).

In relation to the specifics of the Bill, Professor Brown's analysis was cogent:

Contrary to the Government's statements that it is implementing the recommendations of the Review Panel, the Government Response to the Panel (4 July 2013) in fact only clearly accepted nine of the Panel's 22 recommendations (recommendations 1, 2, 3A, 3C, 3E, 4, 11, 12 and 16) - and some of these nine recommendations... are not implemented by these amendments, but rather are inconsistent with them...the most prominent issue which gave rise to the establishment of the Review Panel - the adequacy of provisions governing when and how the making of a complaint to the CMC should be publicly revealed or confirmed - does not appear to be even dealt with at all by these amendments (2014).

He concluded, "It will be a retrograde step, doing lasting damage to the political fabric and reputation of Queensland, if the Legislative Assembly proceeds to pass the Bill in its present form...” For these reasons the Bill may not adhere to the spirit of The Queensland Legislation Handbook (Queensland Government, 2004).

Fitzgerald, in his submission to the same committee stated:

The Bill before this committee takes the final step needed to remove the [Crime and Misconduct] commission's independence entirely and bring it completely under government control ... Neither Newman nor Bleijie ... has knowledge or experience of the complexities involved in balancing personal freedom and public safety through criminal justice.

Fitzgerald (2014) accused the Newman government of trying to undermine the CMC's independence for the future benefit of Liberal National Party politicians. He noted, "Callinan did not recommend the government's outrageous proposal in the Bill that it and it alone decide on senior appointments to the Commission irrespective of the views of the Opposition or advice of the Parliamentary Crime and Misconduct Committee”. He considered Mr Bleijie, “a junior solicitor, appointed to a position which is unsurprisingly far beyond his competence and experience," adding, "His hubris is breathtaking”. He concluded, "the Bill in its present form is a gross abuse of power” (quoted in Vogler \& Viellaris, 2014).

Establishing the Crime and Corruption Commission: The Reformation of Queensland's Premier Crime Fighting Agency 
The CMC’s Acting Chairperson, Dr Ken Levy, in a submission to the Committee, criticised Recommendation 3 of the Callinan and Aroney report, that statutory declarations accompany complaints. He reminded them that some of the most productive investigations by the agency had been instigated as a result of anonymous tips, which constituted about seven per cent of complaints in recent years. Such secret tip-offs resulted in the downfalls of the bogus prince, former Queensland Health financial manager Joel Barlow, for stealing \$16 million from taxpayers, and Gordon Nuttall, a former Labor health minister, for receiving corrupt payments. Introducing a mandatory statutory declaration to accompany complaints to the CMC would eliminate such tips as a valuable source of intelligence (Levy, 2014). Dr Levy further cautioned that if the proposed legislative changes were passed the CMC would become the only Australian watchdog not focused on investigating serious corruption. He said the CMC would have to concentrate on its "primary function”, major crime, when faced with budgetary constraints (Levy, 2014; McKenna, 2014).

Former premier Peter Beattie said the changes would lead to the "government's man in charge of the independent watchdog" and open up corruption in Queensland again (quoted in McKenna, 2014). Submissions by two former CMC Chairpersons were critical of aspects of the Bill. Robert Needham (2014) vehemently opposed first, the removal of the requirement for bipartisan approval by the Parliamentary Committee for appointments of Chairman and part-time Commissioners; second, ministerial control over the Commission's research function; and third, an investigation and hearing power at the discretion of the Parliamentary Commissioner. Another former CMC Chairperson, Professor Ross Martin QC (2014), warned that the looming changes could undermine the independence of the Commission. Five former CMC part-time commissioners, whose experience at the agency spanned 2004 to 2013, also wrote of their concerns with the Bill, chief among which was the CMC's independence from the government of the day and the impact of removing the need for bipartisan support for the appointment of commissioners (Cork, Gow, Gummow, Bell \& Nase, 2014). The Queensland Ombudsman (2014), the Australian Lawyers Alliance (2014), the Bar Association of Queensland (2014), the Queensland Law Society (2014) and the Australian Lawyers for Human Rights (2014) were also critical of important parts of the proposed changes.

Premier Newman and Attorney-General Bleijie defended the unilateral appointment of a chairman (sic) on the grounds that this was no different from the ICAC [the NSW Independent Commission Against Corruption] position (Remeikis, 2014). Paul Williams, a Griffith University lecturer, pointed out that this was meaningless: Queensland's political culture is very different from that of NSW. It has "the longest history of political corruption - perpetrated by both sides of politics - in Australia, and no upper house to prevent it, let alone one outside government control” (2014, p.27).

Establishing the Crime and Corruption Commission: The Reformation of Queensland's Premier Crime Fighting Agency 


\section{How were the Callinan and Aroney review and the Crime and Misconduct and Other Legislation Amendment Bill 2014 deficient?}

What the Callinan and Aroney review omitted may be as informative as what is contained in its report. As pointed out in Professor Prenzler's submission, which was one of more than 60 tendered to the Independent Advisory Panel (Callinan \& Aroney, 2013a: 73-74), the Crime and Misconduct Act was seriously deficient. That particular submission to the Panel was supported by references to a number of studies (for example, Prenzler, 2009; Prenzler \& Faulkner, 2010; Prenzler, Mihinjac \& Porter, 2013). These argued that the 2001 Act was incompatible with democratic and accountable government and with principles of public sector integrity; and that ordinary complainants and whistle-blowers were being treated dismissively because the Act fostered an elitist approach. It concluded that the Act had failed the people of Queensland and therefore required major amendments.

Prenzler’s submission to the Callinan and Aroney review made the following points:

- In order to engender adequate confidence in the legitimacy of the public sector integrity system, the Crime and Misconduct Commission needs to investigate directly and independently a much larger proportion of complaints. This would entail training and employing specialist “civilian” CMC investigators in place of seconded police.

- There also needs to be a more efficient approach to investigations and adjudication. The CMC should prioritise an administrative and inquisitorial approach to matters, with criminal prosecutions only taken after administrative processes are complete. The CMC also needs to be able to direct or over-ride disciplinary decisions by government departments.

- At the same time, there needs to be a decisive shift towards the availability of an independent mediation option for complaints.

- The CMC needs to regionalise its operations by setting up accessible offices in regional centres.

- The task of combating "major crime” needs to be taken away from the CMC. This function distracts from the core task of public sector misconduct management, and it generates a substantial corruption risk (Prenzler, 2012).

While the review's Report reproduced sections of this submission (Prenzler quoted in Callinan \& Aroney, 2013, pp. 73-74), the panel otherwise ignored the scientific evidence on which it was based. The review also did not take into account the large body of relevant empirical work in the international literature. In his submission on the Crime and Misconduct and Other Legislation Amendment Bill, Professor Prenzler stated:

Establishing the Crime and Corruption Commission: The Reformation of Queensland's Premier Crime Fighting Agency 
I would like to encourage the Committee to consider the models provided by the most successful police oversight agency in the world - the Police Ombudsman for Northern Ireland - and the most successful anti-corruption agency - the Hong Kong Independent Commission Against Corruption. An agency that combines both the anti-misconduct and anti-corruption functions of these two agencies would be best for Queensland. This means that both misconduct (for example, neglect of duty and excessive force) and classic corruption would be covered (2014).

In a majority decision, the Legal Affairs and Community Safety committee, which reviewed the government's proposed amendments, recommended the Bill be passed. It found that the model used by the New South Wales Independent Commission Against Corruption, in which the minister refers an appointment to the oversight committee which had the power to veto an appointment, “was appropriate”. Non-government committee members, Labor's Bill Byrne and independent MP Peter Wellington disagreed with the committee's decision and wrote a dissenting report, claiming the Bill was "a signal to Queenslanders that the Newman government is prepared to let Queensland return to the bad old days of the Bjelke-Petersen government where corruption and misconduct were able to flourish" (Legal Affairs and Community Safety Committee, 2014, pp. 100-143). On 7 May 2014 the Crime and Misconduct and Other Legislation Amendment Bill 2014 was passed in the Queensland Parliament. The Bill received assent on 21 May 2014, with the Crime and Misconduct Commission being renamed the Crime and Corruption Commission from 1 July 2014. At the time of writing, police were continuing investigations into whether acting CMC acting chairperson Ken Levy had deliberately misled the PCMC in 2013. His acting appointment was further extended in order to maintain continuity during the transition process after the legislation was passed (Remeikis, 2014).

\section{Conclusion}

A literature review provided a cross section of perspectives on the reforms recommended by the Fitzgerald report and found that vast improvements had been made in accountability and anticorruption mechanisms in Queensland since 1990, but there remained potential for significant improvement. The Callinan-Aroney report had its genesis in the lead-up to the 2012 Queensland election. LNP politicians made it clear at press conferences that they regarded publicity associated with complaints made to the CMC during the campaign as having converted that organisation into a "political weapon". The reality was, however, that there were a very low number of politiciandriven complaints in preceding years that were substantiated, or which warranted a full investigation. Six months after the landslide election win by the LNP, the government initiated a review of the Crime and Misconduct Act, and the resulting report made recommendations aimed at, among other things, discouraging unsubstantiated complaints to the CMC. The panel's focus on politically motivated complaints came at the expense of a broader based approach that might have produced meaningful reform and improvements; instead, its recommendations constituted a further retreat from transparent and accountable government. As Professor Brown maintained, the

Establishing the Crime and Corruption Commission: The Reformation of Queensland's Premier Crime Fighting Agency 
Crime and Misconduct and Other Legislation Amendment Bill 2014 was ostensibly introduced to implement the Callinan and Aroney report's recommendations, but either departed from or went significantly beyond those recommendations, omitting entirely provisions governing when and how the making of a complaint to the CMC should be publicly revealed or confirmed. Inconsistently with its terms of reference, it appeared that the Government's true purpose and expectation was not a review of whether the legislation was serving its intended purposes, but a comprehensive review of the role, powers and operations of the Crime and Misconduct Commission. Tony Fitzgerald, some former CMC chairpersons and commissioners, a former premier, eminent academics and legal associations were vocal in their opposition to the Bill, convinced that it would, in Fitzgerald's (2014) words, "return Queensland governance and public administration to their parlous state in the 1980"”.

\section{Acknowledgements}

The author thanks Professor Tim Prenzler of Griffith University's Centre of Excellence in Policing and Security (CEPS) for reviewing earlier drafts of this article.

\section{Disclosure statement}

No potential conflict of interest was reported by the author.

\section{Notes}

1. Section 2.1 of the Police Service Administration Act 1990 changed the name of the body to the Queensland Police Service.

2. http://www.law.uq.edu.au/academic-staff/staff.php?nm=nicholasaroney\&tab=profilelink

3. Then online at http://www.parliament.qld.gov.au/work-of-committees/committees/LACSC/ inquiries/current-inquiries/CMOLAB2014. 


\section{References}

ABC News, 2012a. 'Qld Government appoints legal experts to review CMC', Australian Broadcasting Corporation, 12 October, retrieved from http://www.abc.net.au/news/201210-11/qld-government-appoints-legal-experts-to-review-cmc/4306864

ABC News, 2012b. As it happened: LNP pulls off crushing win, Australian Broadcasting Corporation 25 March, retrieved from http://www.abc.net.au/news/2012-03-24/liveblog3a-queensland-votes/3910364

Atkins, D., 2012. 'Opinion: Labor dirt campaign enraged voters', The Courier-Mail, 26 March, retrieved from http://www.couriermail.com.au/news/queensland/labor-dirt-enragedvoters/story-fnbwr276-1226309692850

Australian Lawyers for Human Rights, 2014. Submission to the Legislative Affairs and Community Safety Committee, retrieved from https://www.parliament.qld.gov.au/documents/committees/LACSC/2014/CMOLAB2014 /submissions/022.pdf

Australian Lawyers Alliance, 2014. Submission to Legal Affairs and Community Safety Committee on the Crime and Misconduct and Other Legislation Amendment Bill 2014 $(Q L D)$ retrieved from http://www.lawyersalliance.com.au/documents/item/186

Bar Association of Queensland, 2014. Submission to the Legislative Affairs and Community Safety Committee, retrieved from https://www.parliament.qld.gov.au/documents/committees/LACSC/2014/CMOLAB2014 /submissions/012.pdf

Brown A. 2014. Submission to the Legislative Affairs and Community Safety Committee, 14 April, retrieved from https://www.parliament.qld.gov.au/documents/committees/LACSC/2014/CMOLAB2014 /submissions/034.pdf

Callinan, I. and Aroney N., 2013a. Review of the Crime and Misconduct Act and Related Matters: Report of the Independent Advisory Panel. Redacted Version, 28 March, Crown Law, Queensland Government retrieved from http://www.parliament.qld.gov.au/documents/tableOffice/TabledPapers/2013/5413T2447 .pdf

Callinan, I. and Aroney N., 2013b. Review of the Crime and Misconduct Act and Related Matters: Report of the Independent Advisory Panel, Executive Summary, 28 March, retrieved from

http://www.justice.qld.gov.au/_data/assets/pdf_file/0003/178518/CMA_Review_Summar y_Recommendations.pdf

Condon, M., 2013. Three Crooked Kings, St Lucia, UQP.

Cork, J., Gow, D., Gummow, A., Bell J. and Nase, P. 2014. Submission to the Legislative Affairs and Community Safety Committee, 14 April, retrieved from https://www.parliament.qld.gov.au/documents/committees/LACSC/2014/CMOLAB2014 /submissions/033.pdf

Crime and Misconduct Commission, 2002. Annual Report 2001-02, retrieved from http://www.ccc.qld.gov.au/research-and-publications/browse-by-type/cmc-annual-reports

Crime and Misconduct Commission, 2011. Annual Report 2010-11, retrieved from http://www.ccc.qld.gov.au/research-and-publications/browse-by-type/cmc-annual-reports

Establishing the Crime and Corruption Commission: The Reformation of Queensland's Premier Crime Fighting Agency 
Crime and Misconduct Commission, 2011. Public Perceptions of the Public Service: Findings from the 2010 Public Attitudes Survey, retrieved from

http://www.ccc.qld.gov.au/research-and-publications/browse-by-type/public-perceptions$\underline{\text { series }}$

Crime and Misconduct Commission, 2012. 'CMC concludes no official misconduct by Newman in assessment of three BCC-related matters - 16.03.2012', retrieved from

http://www.ccc.qld.gov.au/news-and-media/cmc-media-releases/statement-on-mattersconcerning-brisbane-city-council

Crime and Misconduct Commission, 2013. 'CMC statement in response to recommendations of a Review of the Crime and Misconduct Act 2001 - 03.04.2013', retrieved from http://www.ccc.qld.gov.au/news-and-media/cmc-media-releases/cmc-statement-inresponse-to-recommendations-of-a-review-of-the-crime-and-misconduct-act-2001-2014$\underline{03.04 .2013}$

Fitzgerald T., 1989. Commission of Inquiry into Possible Illegal Activities and Associated Police Misconduct (Fitzgerald Report), Brisbane: GoPrint, retrieved from http://www.ccc.qld.gov.au/about-the-ccc/the-fitzgerald-inquiry

Fitzgerald T., 2014. Submission to the Legislative Affairs and Community Safety Committee, 27 March, retrieved from https://www.parliament.qld.gov.au/documents/committees/LACSC/2014/CMOLAB2014 /submissions/004.pdf

Fleming J. and Lewis, C., 2002. 'The Politics of Police Reform’ pp. 83-96 in Prenzler, T. and Ransley, J. (eds.) Police Reform: building integrity, Sydney: Hawkins Press.

Hurst, D., 2012. 'Spin check: CMC a “political weapon”', Brisbane Times, 16 October 2012 retrieved from http://www.brisbanetimes.com.au/queensland/spin-check-cmc-a-politicalweapon-20121015-27mv7.html

Ironside, R., 2013a. 'Campbell Newman’s public service jobs cull reaches its target of 14,000', The Courier-Mail, 30 May.

Ironside, R., 2013b. 'Labor defies Campbell Newman to reappoint sacked members to PCMC committee', The Courier-Mail, 26 November, retrieved from http://www.couriermail.com.au/news/queensland/newman-warns-alp-on-new-committeemembers/story-fnihsrf2-1226768413430

James, P., 1974. In place of justice: an analysis of a Royal Commission, 1963-1964, Deception Bay: Shield Press.

Keelty, M., 2013. Improving Public Confidence in the Crime and Misconduct Commission, retrieved from

http://www.parliament.qld.gov.au/Documents/TableOffice/TabledPapers/2013/5413T408 8.pdf

Knapp, W., 1972. Report of the Commission to Investigate Alleged Police Corruption, New York City, NY.

Legal Affairs and Community Safety Committee April (2014) Crime and Misconduct and Other Legislation Amendment Bill 2014 Report No. 62, April, retrieved from http://www.parliament.qld.gov.au/documents/committees/LACSC/2014/CMOLAB2014/r pt-062-30Apr2014.pdf

Levy, K., 2013. 'Strong anti-gang laws vital to shield the innocent in bikie battle says CMC boss’, The Courier-Mail, 31 October, retrieved from

Establishing the Crime and Corruption Commission: The Reformation of Queensland's Premier Crime Fighting Agency 
http://www.couriermail.com.au/news/opinion/opinion-strong-antigang-laws-vital-toshield-the-innocent-in-bikie-battle-says-cmc-boss/story-fnihsr9v-1226750041912

Levy K., 2014. Submission to the Legislative Affairs and Community Safety Committee, 11 April, retrieved from https://www.parliament.qld.gov.au/documents/committees/LACSC/2014/CMOLAB2014 /submissions/030.pdf

Lewis, C., 2010. 'Crime and Misconduct Commission: Moving Away from Fitzgerald', pp. 5780 in The Fitzgerald Legacy, Reforming Public Life in Australia and Beyond, Colleen Lewis, Janet Ransley and Ross Homel (eds.), Bowen Hills: Australian Academic Press.

Martin R., 2014. Submission to the Legislative Affairs and Community Safety Committee, 11 April, retrieved from https://www.parliament.qld.gov.au/documents/committees/LACSC/2014/CMOLAB2014 /submissions/025.pdf

McKenna, M., 2014. 'Crime body warns it may not be able to probe corruption', The Australian, 21 April, p 2.

Needham, R., 2014. Submission to the Legislative Affairs and Community Safety Committee, 30 March, retrieved from https://www.parliament.qld.gov.au/documents/committees/LACSC/2014/CMOLAB2014 /submissions/007.pdf

Newman, C. and Bleijie. J., 2013. 'Government to consider CMC report findings', Queensland Government Media Statement, retrieved from http://statements.qld.gov.au/Statement/2013/4/3/government-to-consider-cmc-reportfindings

news.com.au, 2014. Levy investigation suspended in Qld. 9 May retrieved from http://www.news.com.au/national/breaking-news/levy-investigation-suspended-inqld/story-e6frfku9-1226911848859

Patten, C. and Hayes M., 1999. The Report of the Independent Commission on Policing for Northern Ireland, retrieved from http://cain.ulst.ac.uk/issues/police/patten/patten99.pdf

Palaszczuk, A., 2013. Secret Report on CMC Raises Concerns, retrieved from http://www.queenslandlabor.org/2013/04/03/secret-report-on-cmc-raises-concerns/

Prasser S. and Aroney, N., 2009. 'Real Constitutional Reform After Fitzgerald: Still Waiting for Godot', Griffith Law Review, 18(3): 596-620.

Prasser, S., 2012. 'The Forthcoming Queensland Election', Democratic Audit Discussion Paper, retrieved from http://democraticaudit.org.au/wpcontent/uploads/2012/01/prasser_qld2012.pdf

Prenzler, T., 2009. 'Reform in Politics, Criminal Justice and the Police in Post-Fitzgerald Queensland: An Assessment', Griffith Law Review, 18(3): 576-595.

Prenzler, T. and Faulkner, N., 2010. 'Towards a Model Public Sector Integrity Commission', Australian Journal of Public Administration, 69(3): 251-262.

Prenzler, T., 2012. 'Submission to the Review of the Crime and Misconduct Act 2001', unpublished correspondence, 12 November.

Prenzler, T., Mihinjac, M. and Porter, L., 2013. 'Reconciling Stakeholder Interests in Police Complaints and Discipline Systems’, Police Practice and Research: An International Journal.

Prenzler T., 2014. Submission to the Legislative Affairs and Community Safety Committee, 31 March, retrieved from

Establishing the Crime and Corruption Commission: The Reformation of Queensland's Premier Crime Fighting Agency 
https://www.parliament.qld.gov.au/documents/committees/LACSC/2014/CMOLAB2014 /submissions/008.pdf

Queensland Government, 2004. The Queensland Legislation Handbook: Governing Queensland, Queensland Department of the Premier and Cabinet, retrieved from https://www.legislation.qld.gov.au/Leg_Info/publications/Legislation_Handbook.pdf

Queensland Government, 2012. Review of the Crime and Misconduct Act 2001 Terms of Reference, retrieved from http://www.justice.qld.gov.au/cmareview/about/terms-ofreference

Queensland Government 2014. Crime and Misconduct and Other Legislation Amendment Bill 2014 Explanatory Notes retrieved from https://www.legislation.qld.gov.au/Bills/54PDF/2014/CrimeMisconductOLAB14E.pdf

Queensland Law Society, 2014. Submission to the Legislative Affairs and Community Safety Committee, 11 April 2014 retrieved from https://www.parliament.qld.gov.au/documents/committees/LACSC/2014/CMOLAB2014 /submissions/029.pdf

Queensland Ombudsman, 2014. Submission to the Legislative Affairs and Community Safety Committee, 10 April 2014 retrieved from https://www.parliament.qld.gov.au/documents/committees/LACSC/2014/CMOLAB2014 /submissions/019.pdf

Queensland Parliament, 2013. Parliamentary Crime and Misconduct Committee - Inquiry into the Crime and Misconduct Commission's release and destruction of Fitzgerald Commission Inquiry documents; The Honourable Ian Callinan AC and Professor Nicholas Aroney - Review of the Crime and Misconduct Act 2001 and related matters. Government Response, retrieved from http://www.parliament.qld.gov.au/documents/tableOffice/TabledPapers/2013/5413T2923 .pdf

Ransley, J. and Johnstone, R., 2009. 'The Fitzgerald Symposium: An Introduction', Griffith Law Review, 18(3): $531-543$.

Remeikis, A. 2013a. 'Ombudsman wants to keep powers', Brisbane Times, 19 April, retrieved from http://www.brisbanetimes.com.au/queensland/ombudsman-wants-to-keep-powers20130419-2i3pp.html\#ixzz2ZMiD1ONl

Remeikis, A. 2013b. 'Ken Levy hits back at committee investigating him', Brisbane Times, 21 November, retrieved from http://www.brisbanetimes.com.au/queensland/ken-levy-hitsback-at-committee-investigating-him-20131121-2xysd.html

Remeikis, A., 2014. 'CMC changes to go ahead', Brisbane Times, 1 May, retrieved from http://www.brisbanetimes.com.au/queensland/cmc-changes-to-go-ahead-20140501zr2mg.html

Ryan, B., 2013. 'CMC row intensifies after secret documents tabled in Qld parliament' $A B C$ News, 22 November, retrieved from http://www.abc.net.au/news/2013-11-21/cmc-rowintensifies-after-secret-documents-tabled-in-qld-parlia/5106974

Smail, S., Ryan, B. and staff, 2013. Call for judicial inquiry after Qld Government sacks PCMC members, retrieved from http://www.abc.net.au/news/2013-11-22/call-for-judicialinquiry-after-qld-government-sacks-pcmc/5109756

Establishing the Crime and Corruption Commission: The Reformation of Queensland's Premier Crime Fighting Agency 
Timmins, P., 2013. Queensland CMC report floats drastic right to information change, posted 4 April, retrieved from http://foi-privacy.blogspot.com.au/2013/04/queensland-cmc-reportfloats-drastic.html\#.UeDb7tKLDGF

Vogler, S. and Viellaris R., 2014. 'Fitzgerald dumps on CMC plan', The Courier-Mail, 29 March, p. 27.

Wanna J. and Arklay T., 2010. The Ayes Have It: The History of the Queensland Parliament 1957-1989, ANU E Press, retrieved from http://epress.anu.edu.au?p=69721

Williams, P., 2014. 'Purge the urge to undermine corruption-busting body', The Courier-Mail, 7 May, pp.26-27.

Withey A. and Dorsett, J., 2013. 'Fears CMC recommendations will discourage whistleblowers,' ABC News, 4 April, retrieved from http://www.abc.net.au/news/2013-04-04/fears-cmcrecommendations-will-discourage-whistleblowers/4608820

Wood J., 1997. Royal Commission into the New South Wales Police Service, Final Report, Volumes I-III, NSW Government Printer.

\section{Legislation}

Criminal Law (Criminal Organisations Disruption) Amendment Bill 2013 (Qld.)

Crime and Misconduct Act 2001 (Qld)

Crime and Misconduct and Other Legislation Amendment Bill 2014 (Qld.)

Crime and Misconduct and Other Legislation Amendment Act 2014 (Qld.)

Criminal Law Amendment (Public Interest Declarations) Amendment Act 2013 (Qld.)

Ombudsman Act 2001 (Qld.)

Police Service Administration Act 1990 (Qld.)

Right to Information Act 2009 (Qld.)

Vicious Lawless Association Disestablishment (VLAD) Act 2013 (Qld.)

Establishing the Crime and Corruption Commission: The Reformation of Queensland's Premier Crime Fighting Agency 